\title{
Development of fast formation process for synthesizing submicron lead magnesium niobate perovskite powder
}

\author{
Chung-Hsin $\mathrm{Lu} *$, Hsien-Sheng Yang \\ Department of Chemical Engineering, National Taiwan University, Taipei, Taiwan, ROC
}

Received 25 April 2000; accepted 17 November 2000

\begin{abstract}
The characteristics of the solid-state reaction for synthesizing ultrafine $\mathrm{Pb}\left(\mathrm{Mg}_{1 / 3} \mathrm{Nb}_{2 / 3}\right) \mathrm{O}_{3}$ powder using a new percursor, $\mathrm{Mg}_{4} \mathrm{Nb}_{2} \mathrm{O}_{9}$ have been investigated. Quenching the mixtures of $\mathrm{Mg}_{4} \mathrm{Nb}_{2} \mathrm{O}_{9}$ with excess $\mathrm{PbO}$ at $850-900^{\circ} \mathrm{C}$ without further soaking rapidly leads to the complete formation of perovskite phase without pyrochlore phase. Some residual MgO exists in samples; however, $\mathrm{MgO}$ is completely eliminated by nitric acid, thereby producing monophasic $\mathrm{Pb}\left(\mathrm{Mg}_{1 / 3} \mathrm{Nb}_{2 / 3}\right) \mathrm{O}_{3}$. This process confirms the feasibility to synthesize $\mathrm{Pb}\left(\mathrm{Mg}_{1 / 3} \mathrm{Nb}_{2 / 3}\right) \mathrm{O}_{3}$ in a fast reaction route. The addition of excess $\mathrm{PbO}$ enhances the formation rate of $\mathrm{Pb}\left(\mathrm{Mg}_{1 / 3} \mathrm{Nb}_{2 / 3}\right) \mathrm{O}_{3}$, and also decreases the minimum temperature required for preparing pure perovskite phase. The particle size of obtained $\mathrm{Pb}\left(\mathrm{Mg}_{1 / 3} \mathrm{Nb}_{2 / 3}\right) \mathrm{O}_{3}$ powder is within the range of submicron meter, and increases with the increasing amount of $\mathrm{PbO}$ used. (C) 2001 Elsevier Science B.V. All rights reserved.
\end{abstract}

Keywords: Lead magnesium niobate; Powder; Synthesis; Relaxor

\section{Introduction}

Lead magnesium niobate $\mathrm{Pb}\left(\mathrm{Mg}_{1 / 3} \mathrm{Nb}_{2 / 3}\right) \mathrm{O}_{3}$, a wellknown ferroelectric relaxor with perovskite structure, exhibits high permittivity, large electrostrictivity, and diffuse phase transition characteristics. Since its first discovery by Smolenskii and Agranovskaya in 1958 [1], $\mathrm{Pb}\left(\mathrm{Mg}_{1 / 3} \mathrm{Nb}_{2 / 3}\right) \mathrm{O}_{3}$ has been intensively investigated and widely used in dielectric and piezoelectric devices with high quality and reliability [2-8]. In preparation via the solid-state reaction using oxide mixtures, pyrochlore phases with relatively low dielectric constant are inevitably formed with $\mathrm{Pb}\left(\mathrm{Mg}_{1 / 3} \mathrm{Nb}_{2 / 3}\right) \mathrm{O}_{3}$, and these phases significantly reduce the dielectric constant of obtained ceramics. Hence, in order to eliminate the residual pyrochlore phases, Swartz and Shrout developed the columbite process for synthesizing $\mathrm{Pb}\left(\mathrm{Mg}_{1 / 3} \mathrm{Nb}_{2 / 3}\right) \mathrm{O}_{3}$ [9]. In this process, a precursor, $\mathrm{MgNb}_{2} \mathrm{O}_{6}$ with columbite structure is prepared which subsequently reacts with $\mathrm{PbO}$ to form around $98 \%$ $\mathrm{Pb}\left(\mathrm{Mg}_{1 / 3} \mathrm{Nb}_{2 / 3}\right) \mathrm{O}_{3}$. In the columbite process, an excess amount of $\mathrm{MgO}$ has to be added into the reactants for

\footnotetext{
* Corresponding author. Fax: + 886-2-3623040.
}

E-mail address: chlu@ccms.ntu.edu.tw (C.-H. Lu). suppressing the formation of pyrochlore phase and to obtain pure perovskite phase. However, excess $\mathrm{MgO}$ will exist as discrete particles which in turn deteriorate the dielectric properties [10].

Recently Joy and Sreedhar reported that the perovskite $\mathrm{Pb}\left(\mathrm{Mg}_{1 / 3} \mathrm{Nb}_{2 / 3}\right) \mathrm{O}_{3}$ can be stabilized by adding excess $\mathrm{MgO}$ in the precursors [11], and further suggested that use of the precursor $\mathrm{Mg}_{4} \mathrm{Nb}_{2} \mathrm{O}_{9}$ instead of columbite precursor $\mathrm{MgNb}_{2} \mathrm{O}_{6}$ is helpful to prepare the single phase $\mathrm{Pb}\left(\mathrm{Mg}_{1 / 3} \mathrm{Nb}_{2 / 3}\right) \mathrm{O}_{3}$. Hence, it is thought worthwhile to investigate in detail, the reaction processes for the formation of $\mathrm{Pb}\left(\mathrm{Mg}_{1 / 3} \mathrm{Nb}_{2 / 3}\right) \mathrm{O}_{3}$ using the new precursor $-\mathrm{Mg}_{4} \mathrm{Nb}_{2} \mathrm{O}_{9}$. We report influence of the amount of $\mathrm{PbO}$ on the formation of perovskite phase and the microstructure of $\mathrm{Pb}\left(\mathrm{Mg}_{1 / 3} \mathrm{Nb}_{2 / 3}\right) \mathrm{O}_{3}$. Through this study, a fast solid-state synth process for preparing monophasic $\mathrm{Pb}\left(\mathrm{Mg}_{1 / 3} \mathrm{Nb}_{2 / 3}\right) \mathrm{O}_{3}$ powder with submicron size was successfully developed.

\section{Experimental procedure}

$\mathrm{Mg}_{4} \mathrm{Nb}_{2} \mathrm{O}_{9}$ was prepared from $\mathrm{MgO}$ and $\mathrm{Nb}_{2} \mathrm{O}_{5}$ (the reagent-grade) by solid-state reaction. $\mathrm{MgO}$ powder was heated at $800^{\circ} \mathrm{C}$ for $30 \mathrm{~min}$ to eliminate the $\mathrm{CO}_{2}$ 
and $\mathrm{H}_{2} \mathrm{O}$ absorbed on the particle surfaces. $\mathrm{Nb}_{2} \mathrm{O}_{5}$ and $\mathrm{MgO}$ were mixed in stoichiometric ratio in ethyl alcohol by ball-milling for $48 \mathrm{~h}$. The mixtures were dried and heated at $1000^{\circ} \mathrm{C}$ for $2 \mathrm{~h}$ to form pure $\mathrm{Mg}_{4} \mathrm{Nb}_{2} \mathrm{O}_{9}$ with a hexagonal unit cell [12]. $\mathrm{PbO}$ and the niobate precursor- $\mathrm{Mg}_{4} \mathrm{Nb}_{2} \mathrm{O}_{9}$ were mixed in molar ratios of 3: 1, 3.1: 1, and 3.2: 1 (denoted for systems $\mathrm{A}-\mathrm{C}$ ) by

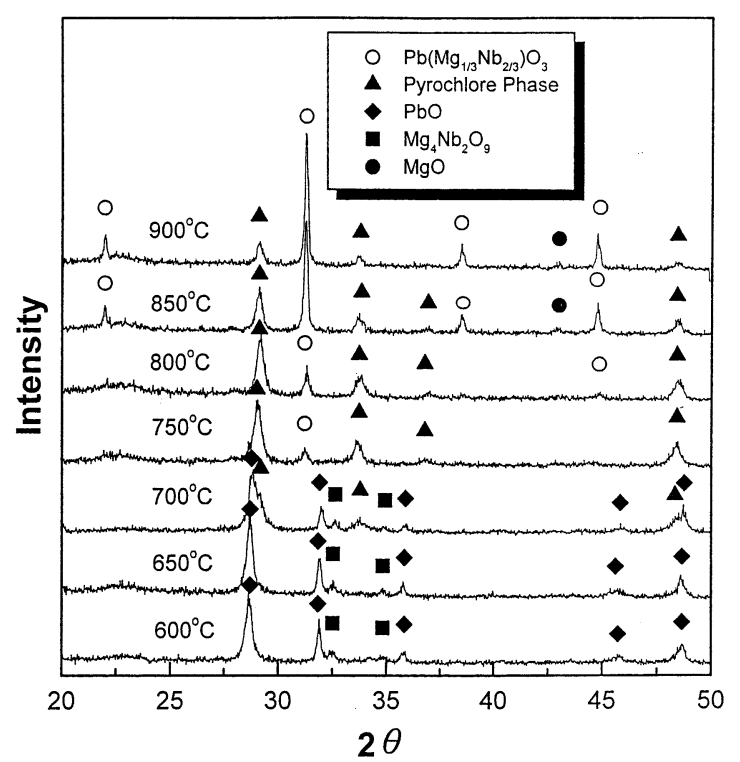

Fig. 1. X-ray diffraction patterns of the mixtures of $\mathrm{PbO}$ and $\mathrm{Mg}_{4} \mathrm{Nb}_{2} \mathrm{O}_{9}$ (molar ratio = 3: 1) quenched at various temperatures.

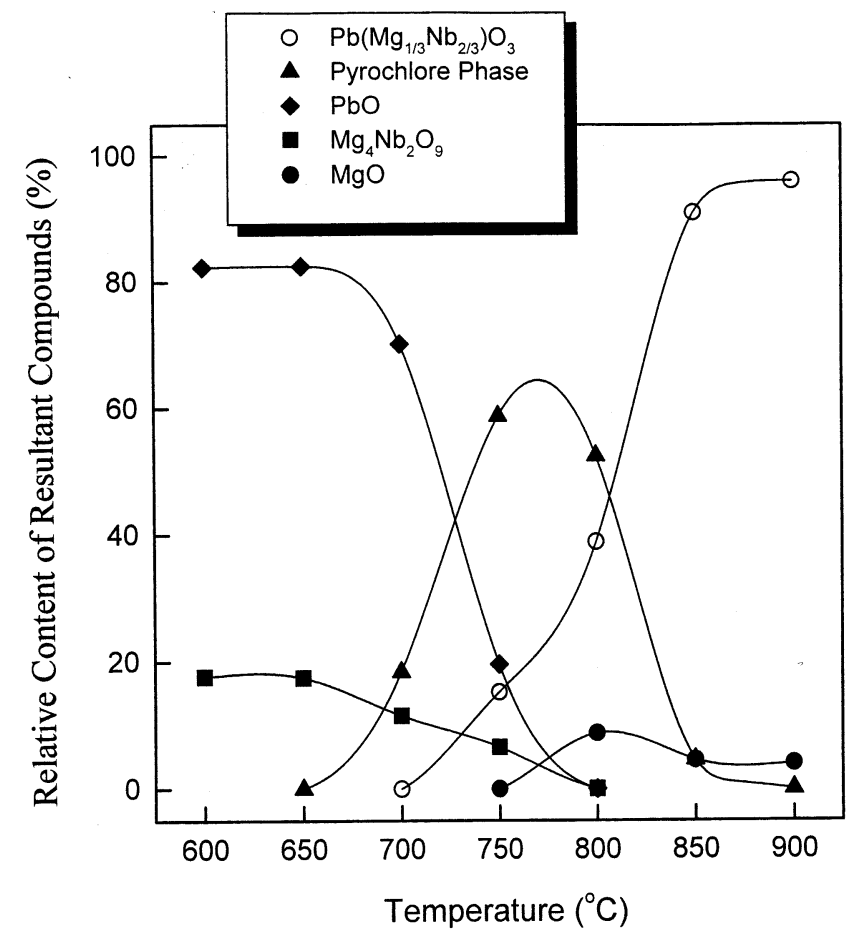

Fig. 2. Relative content of resultant compounds for the mixtures of $\mathrm{PbO}$ and $\mathrm{Mg}_{4} \mathrm{Nb}_{2} \mathrm{O}_{9}$ (molar ratio $=3.1: 1$ ) heated at various temperatures. ball-milling for $48 \mathrm{~h}$. For comparing the formation of $\mathrm{Pb}\left(\mathrm{Mg}_{1 / 3} \mathrm{Nb}_{2 / 3}\right) \mathrm{O}_{3}$ in the process using $\mathrm{Mg}_{4} \mathrm{Nb}_{2} \mathrm{O}_{9}$ and that in the columbite process, $\mathrm{PbO}$ and $\mathrm{MgNb}_{2} \mathrm{O}_{6}$ were mixed by the identical ball-milling process in system $\mathrm{D}$. The above four kinds of mixtures were heated at temperature ranging from 600 to $900^{\circ} \mathrm{C}$ at a ramp rate of $10^{\circ} \mathrm{C} / \mathrm{min}$. After the set temperature reached, the specimens were subsequently quenched in air without further soaking. The quenched specimens were examined by powder XRD with $\mathrm{CuK} \alpha$ radiation to identify the formed phases. The relative content of perovskite phase existing in the specimens was calculated from the following equation:

$X_{\text {per }}(\%)=100 I_{\text {per }} /\left(I_{\text {per }}+I_{\text {pyr }}+I_{\mathrm{Mgo}}\right)$

where $I_{\text {per }}, I_{\text {pyr }}$ and $I_{\mathrm{Mgo}}$ refer to the intensity of the (110) reflection of the perovskite phase, that of the (222) reflection of the pyrochlore phase, that of the (200) of $\mathrm{MgO}$, respectively. The morphology of the obtained powder was examined by scanning electron microscopy (SEM).

\section{Results and discussion}

For realizing the phase development in system A during heating processes, the precursor powder was quenched at elevated temperatures and examined by XRD. The representative XRD patterns for quenched specimens are shown in Fig. 1. After heating at $700^{\circ} \mathrm{C}$, pyrochlore phase is formed with unreacted $\mathrm{PbO}$ and $\mathrm{Mg}_{4} \mathrm{Nb}_{2} \mathrm{O}_{9}$. Heating up to $750^{\circ} \mathrm{C}, \mathrm{Pb}\left(\mathrm{Mg}_{1 / 3} \mathrm{Nb}_{2 / 3}\right) \mathrm{O}_{3}$ begins to appear, and $\mathrm{PbO}$ and $\mathrm{Mg}_{4} \mathrm{Nb}_{2} \mathrm{O}_{9}$ all disappear. With a rise in the temperature, the amount of $\mathrm{Pb}\left(\mathrm{Mg}_{1 / 3} \mathrm{Nb}_{2 / 3}\right) \mathrm{O}_{3}$ rapidly increases with the correlative decrease in the amount of pyrochlore phase. However, even heating up to $900^{\circ} \mathrm{C}$, pyrochlore phase still parasitically coexists with $\mathrm{Pb}\left(\mathrm{Mg}_{1 / 3} \mathrm{Nb}_{2 / 3}\right) \mathrm{O}_{3}$, and no pure perovskite phase can be obtained. In addition, $\mathrm{MgO}$ is also found to appear in the products.

For obtaining pure $\mathrm{Pb}\left(\mathrm{Mg}_{1 / 3} \mathrm{Nb}_{2 / 3}\right) \mathrm{O}_{3}$, excess amounts of $\mathrm{PbO}$ were added in systems $\mathrm{B}$ and $\mathrm{C}$. The relative content of resultant compounds versus quenching temperatures in system B is plotted in Fig. 2. The relative content of the formed compounds was estimated by calculating the ratios of the intensity of the major peak of phase $i / \Sigma$ intensity of the major peak of phase $i$ for each compound. Fig. 2 indicates that no reactions occur till the temperature reaches $700^{\circ} \mathrm{C}$, after which pyrochlore phase begins to appear. In both system $\mathrm{A}$ and $\mathrm{B}$, the amount of pyrochlore phase reaches a maximum at $800^{\circ} \mathrm{C}$; however, the amount of pyrochlore phase in the latter system is much less than that in the former system. Like system $\mathrm{A}$, the formation of $\mathrm{Pb}\left(\mathrm{Mg}_{1 / 3} \mathrm{Nb}_{2 / 3}\right) \mathrm{O}_{3}$ initiates at $750^{\circ} \mathrm{C}$. After heating up to $900^{\circ} \mathrm{C}$ without further soaking, $\mathrm{Pb}\left(\mathrm{Mg}_{1 / 3} \mathrm{Nb}_{2 / 3}\right) \mathrm{O}_{3}$ 


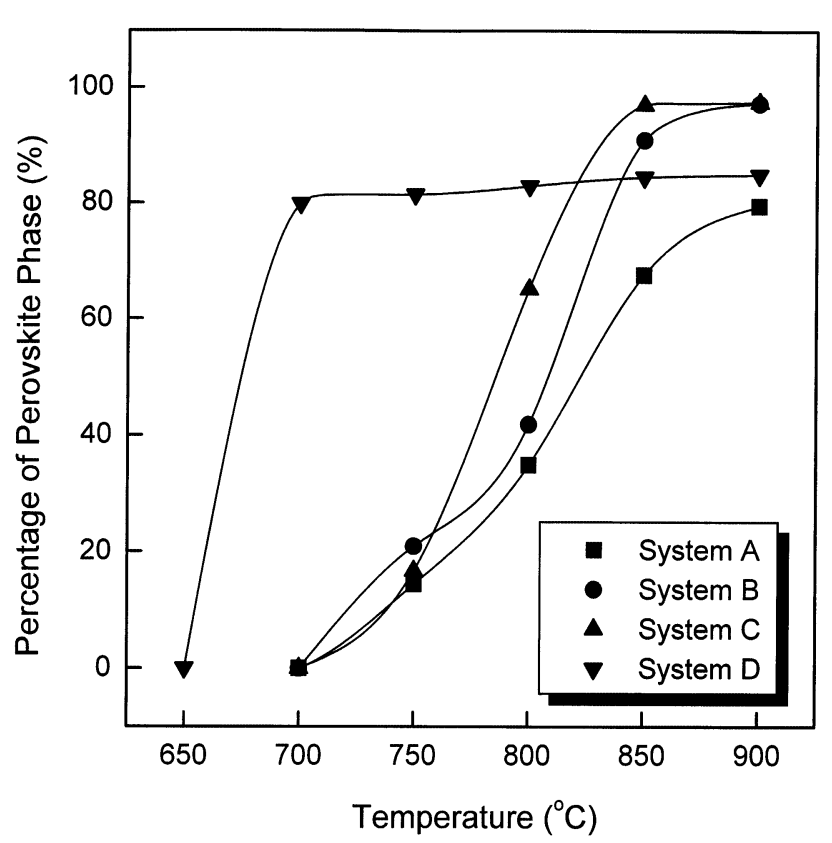

Fig. 3. Content of $\mathrm{Pb}\left(\mathrm{Mg}_{1 / 3} \mathrm{Nb}_{2 / 3}\right) \mathrm{O}_{3}$ perovskite versus the quenching temperature for four different systems.

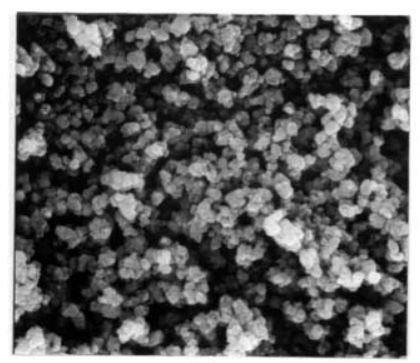

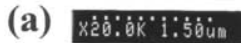

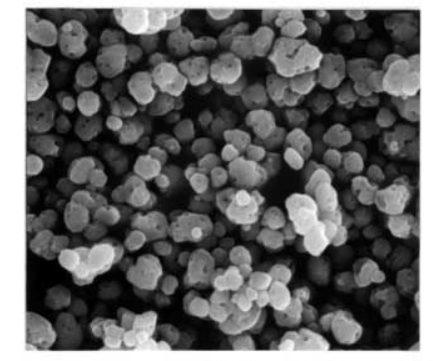

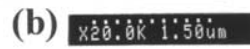

Fig. 4. Scanning electron micrographs of the powders obtained in: (a) system $\mathrm{A}$; and (b) system $\mathrm{C}$ by quenching the mixtures at $900^{\circ} \mathrm{C}$ and leached by nitric acid.

is completely formed without any pyrochlore phase, although some residual $\mathrm{MgO}$ exists. The $900^{\circ} \mathrm{C}-$ quenched powder was then washed by nitric acid $(2 \mathrm{M})$ for $8 \mathrm{~h}$. It is found that all $\mathrm{MgO}$ was eliminated by nitric acid, and monophasic $\mathrm{Pb}\left(\mathrm{Mg}_{1 / 3} \mathrm{Nb}_{2 / 3}\right) \mathrm{O}_{3}$ was obtained. The above results confirm that only heating $\mathrm{Mg}_{4} \mathrm{Nb}_{2} \mathrm{O}_{9}$-consisted precursors up to $900^{\circ} \mathrm{C}$ results in the complete formation of $\mathrm{Pb}\left(\mathrm{Mg}_{1 / 3} \mathrm{Nb}_{2 / 3}\right) \mathrm{O}_{3}$. The reac- tion processes for the formation of $\mathrm{Pb}\left(\mathrm{Mg}_{1 / 3} \mathrm{Nb}_{2 / 3}\right) \mathrm{O}_{3}$ is considered as below:

$\mathrm{PbO}+\mathrm{Mg}_{4} \mathrm{Nb}_{2} \mathrm{O}_{9} \rightarrow$ Pyrochlore phase

Pyrochlore phase $\rightarrow \mathrm{Pb}\left(\mathrm{Mg}_{1 / 3} \mathrm{Nb}_{2 / 3}\right) \mathrm{O}_{3}+\mathrm{MgO}$

The composition of pyrochlore phase formed in this study is believed to contain excess magnesium species compared with that in the normal columbite process since the magnesium content in $\mathrm{Mg}_{4} \mathrm{Nb}_{2} \mathrm{O}_{9}$ is four times higher than that in $\mathrm{MgNb}_{2} \mathrm{O}_{6}$. The excess magnesium species are driven out from pyrochlore phase to produce $\mathrm{MgO}$ when $\mathrm{Pb}\left(\mathrm{Mg}_{1 / 3} \mathrm{Nb}_{2 / 3}\right) \mathrm{O}_{3}$ is formed.

Fig. 3 illustrates the percentage of perovskite phase without residual $\mathrm{MgO}$ for systems $\mathrm{A}-\mathrm{D}$ versus the quenching temperature. The addition of excess $\mathrm{PbO}$ significantly enhances the formation of $\mathrm{Pb}\left(\mathrm{Mg}_{1 / 3} \mathrm{Nb}_{2 / 3}\right) \mathrm{O}_{3}$ at low temperatures. In system $\mathrm{A}$, $\mathrm{Pb}\left(\mathrm{Mg}_{1 / 3} \mathrm{Nb}_{2 / 3}\right) \mathrm{O}_{3}$ coexists with pyrochlore phase after heating up to $900^{\circ} \mathrm{C}$. However, pure perovskite phase is formed in systems $\mathrm{B}$ and $\mathrm{C}$ by quenching the precursors at 900 and $850^{\circ} \mathrm{C}$, respectively. It is noted that the required minimum temperature for synthesizing pure $\mathrm{Pb}\left(\mathrm{Mg}_{1 / 3} \mathrm{Nb}_{2 / 3}\right) \mathrm{O}_{3}$ decreases with increasing the amount of excess $\mathrm{PbO}$. The existence of excess $\mathrm{PbO}$ is believed to suppress the formation of pyrochlore phase which is produced by the volatilization of $\mathrm{PbO}$ and promotes the formation of $\mathrm{Pb}\left(\mathrm{Mg}_{1 / 3} \mathrm{Nb}_{2 / 3}\right) \mathrm{O}_{3}$ by the liquid phase of $\mathrm{PbO}$ [14,15]. On the other hand, although $\mathrm{Pb}\left(\mathrm{Mg}_{1 / 3} \mathrm{Nb}_{2 / 3}\right) \mathrm{O}_{3}$ is rapidly formed at low temperatures in the columbite process (system D), it is not possible to remove the pyrochlore phase by quenching the precursors up to $900^{\circ} \mathrm{C}$. Thus, it is revealed that the developed process in this study is more efficient than the columbite process for preparing $\mathrm{Pb}\left(\mathrm{Mg}_{1 / 3} \mathrm{Nb}_{2 / 3}\right) \mathrm{O}_{3}$ with respect to the heating temperature and time $[9,13]$.

The microstructure of the $900^{\circ} \mathrm{C}$-quenched powder after the acid-leaching process was examined by SEM. The particle size in systems $\mathrm{A}-\mathrm{C}$ is within the order of submicron meter. The particle size of the powder in system A (Fig. 4(a)), system B, and system C (Fig. 4(b)) is $\sim 0.1,0.2$, and $0.3 \mu \mathrm{m}$, respectively. It is found that the particle size greatly increases with increasing the amount of $\mathrm{PbO}$ probably due to the liquid-phase sintering of excess $\mathrm{PbO}$. It is also seen that plenty of dimples exist on the obtained powder (Fig. 4(b)). On the other hand, before the acid-leaching process no dimples exist on the powder, and the presence of a lot of tiny $\mathrm{MgO}$ particles are observed. Once $\mathrm{MgO}$ is leached out by the acid-leaching process, the removal of $\mathrm{MgO}$ results in the hollows in the original powder and forms the dimple-like morphology. The particle size of $\mathrm{Pb}\left(\mathrm{Mg}_{1 / 3} \mathrm{Nb}_{2 / 3}\right) \mathrm{O}_{3}$ prepared in this study method is found to be relatively smaller than that prepared via the columbite precursor process [13]. The $\mathrm{Pb}\left(\mathrm{Mg}_{1 / 3} \mathrm{Nb}_{2 / 3}\right) \mathrm{O}_{3}$ powder with fine particle size is regarded to have advantage for lowering sintering temperature. 


\section{Conclusions}

The fast formation process for synthesizing $\mathrm{Pb}\left(\mathrm{Mg}_{1 / 3} \mathrm{Nb}_{2 / 3}\right) \mathrm{O}_{3}$ using a new niobate precursor$\mathrm{Mg}_{4} \mathrm{Nb}_{2} \mathrm{O}_{9}$ has been developed in this study. Heating the mixtures of $\mathrm{Mg}_{4} \mathrm{Nb}_{2} \mathrm{O}_{9}$ and excess $\mathrm{PbO}$ up to $850-900^{\circ} \mathrm{C}$ without further soaking results in the complete formation of perovskite phase with residual $\mathrm{MgO}$. Leaching the obtained products with dilute nitric acid completely removes residual $\mathrm{MgO}$, thereby producing the monophasic $\mathrm{Pb}\left(\mathrm{Mg}_{1 / 3} \mathrm{Nb}_{2 / 3}\right) \mathrm{O}_{3}$ powder. The amount of $\mathrm{PbO}$ plays an important role in synthesis of $\mathrm{Pb}\left(\mathrm{Mg}_{1 / 3} \mathrm{Nb}_{2 / 3}\right) \mathrm{O}_{3}$. Increasing the amount of $\mathrm{PbO}$ not only enhances the formation rate of perovskite phase, but also decreases the required temperature for obtaining pure perovskite phase. The particle size of obtained $\mathrm{Pb}\left(\mathrm{Mg}_{1 / 3} \mathrm{Nb}_{2 / 3}\right) \mathrm{O}_{3}$ powder is within the range of submicron meter, and is increased with the increasing amount of $\mathrm{PbO}$.

\section{References}

[1] G.A. Smolenskii, A.I. Agranovskaya, Sov. Phys.-Tech. Phys. 3 (1958) 1380.

[2] V.A. Bokov, I.E. Mylnikova, Sov. Phys. Solid State 3 (1961) 613.

[3] S.L. Swartz, T.R. Shrout, W.A. Schulze, L.E. Cross, J. Am. Ceram. Soc. 67 (1984) 311.

[4] M. Lejeune, J.P. Boilot, Am. Ceram. Soc. Bull. 65 (1986) 679.

[5] L.E. Cross, Ferroelectrics 76 (1987) 241.

[6] D.H. Kang, K.H. Yoon, Ferroelectrics 87 (1988) 255.

[7] H.C. Wang, W.A. Schulze, J. Am. Ceram. Soc. 73 (1990) 825.

[8] B.H. Kim, O. Sakurai, N. Wakiya, N. Mizutani, Mater. Res. Bull. 32 (1997) 451.

[9] S.L. Swartz, T.R. Shrout, Mater. Res. Bull. 17 (1982) 1245.

[10] E. Goo, T. Yamamoto, K. Okazaki, J. Am. Ceram. Soc. C 69 (1986) 188.

[11] P.A. Joy, K. Sreedha, J. Am. Ceram. Soc. 80 (1997) 770.

[12] E.F. Bertaut, L. Corliss, F. Forrat, R. Aleonard, R. Pauthenet, Phys. Chem. Solids 21 (1961) 234.

[13] C.H. Lu, J.T. Lee, J. Ceram. Soc. Jpn. 103 (1995) 1122.

[14] M. Lejeune, J.P. Boilot, Am. Ceram. Soc. Bull. 64 (1985) 679.

[15] C.H. Lu, S.C. Fu, Mater. Lett. 27 (1996) 71. 